\title{
The Role and the Significance of the Russian Federation in the European Higher Education Area*
}

\author{
Dmitri Ezhevski \\ Faculty of Law \\ Department of Constitutional Law and Constitutional Jurisdiction \\ Peoples' Friendship University of Russia (RUDN University) \\ 6 Miklukho-Maklaya Street, Moscow, 117198, Russian Federation \\ E-mail: Dima0404@mail.ru
}

\author{
Mariya Dementyeva \\ Faculty of Russian Language and General Subjects \\ Department of Chemistry and Biology \\ Peoples' Friendship University of Russia (RUDN \\ University) \\ 6 Miklukho-Maklaya Street, Moscow, 117198, Russian \\ Federation \\ E-mail: dementyeva_mv@rudn.university
}

\author{
Elena Shaleeva \\ Academy of Engineering \\ Department of Foreign Languages \\ Peoples' Friendship University of Russia (RUDN \\ University) \\ 6 Miklukho-Maklaya Street, Moscow, 117198, Russian \\ Federation \\ E-mail: LenaShaleeva@mail.ru
}

\begin{abstract}
The mechanisms of the European Higher Education Area can help strengthen Russia's relations with Europe. However, the effectiveness of Russian policy in this area is limited by the lack of systematic planning for the long term perspective.
\end{abstract}

Keywords - education; Bologna Convention; Bologna process; knowledge economy; politics; university; education reform

\section{INTRODUCTION}

The second half of the 20th century is considered to be the period of large-scale development regarding higher education. As a result of the development of information and communication technologies, education is gradually becoming an important factor in development, elaboration and growth.

In the era of globalization, education, especially higher education, is gradually beginning to not only be a key component of innovative development, but it is also becoming a driving force of political and social transformations at all levels including the global, country and in-country levels, thereby acquiring a "politics-forming" function. The knowledge economy has also become a factor of global influence and strength for a number of different countries and states.

Despite this, experts in the fields of world politics and

*This paper was financially supported by the Ministry of Education and Science of the Russian Federation on the program to improve the competitiveness of Peoples' Friendship University (RUDN University) among the world's leading research and education centers in the 2016-2020 (The Agreement number 02.A03.21.0008) international relations still pay very limited attention to the international political component of the educational problems; the study of the above problems is in most cases left to specialists from other fields and areas of study (economists, historians, teachers). The problem is now becoming even more relevant and the relevance of this study lies, among other things, in overcoming this trend.

\section{REFORM OF RUSSIAN EDUCATION}

Since the beginning of the 2000s, the Russian system of higher professional education and higher education systems of the European Union countries have been involved in the process of reforming, modernizing and synchronizing their systems in accordance with the new realities and challenges of globalization. The Bologna process is one of the most vivid and also one of the most compelling examples of political cooperation in the sphere of higher education.

The recognition as well as the perception of the increasingly important and, to some extent, decisive role of higher education in the socio-political development of Europe lies at the very heart of the Bologna process, facing such serious challenges and major concerns as globalization, the loss of leadership in the field of technological development as well as the aging of the population. Russia is very well known for its strong tradition of higher education, but in the face of increasing global competition and rapid scientific and technological progress, Russian higher education is nowadays facing the same problems as the European higher education.

Russia's entry into the Bologna process was driven by the desire to modernize the country's educational system in 
cooperation and collaboration with European partners. Moreover, from the political point of view, it marked the priority of the European trend of development of Russia in the early 2000s and, more importantly, denoted the desire for full participation in the key European initiative and the understanding of the importance of overcoming of the "isolationism" in the educational sphere.

After ten years, it is relevant to analyze the results obtained from Russia's participation in this integration initiative. In the conditions of political turbulence that characterizes the relations between Russia and the Europe Union in recent months, the issue of education can become one of the key areas for rapprochement, reestablishment and mending of interstate relations [1].

From this perspective and within this framework, an analysis of the political and social potential of Russia's participation in the Bologna system calls for an in-depth and profound scientific study, in particular - the exploration of opportunities for increase regarding the impact of Russian participation in the European Higher Education Area (EHEA) and to analyze the possibilities for the practical use of the Bologna process for building a strategic partnership with The European Union and the CIS region.

\section{THE COMPLEXITY OF INTEGRATING RUSSIAN HIGHER EDUCATION INTO THE BOLOGNA PROCESS}

The problem of the political significance of Russia's participation in the Bologna process has a number of aspects, which have been worked out to varying extents in the available scientific literature. In general, despite the fact that Russian, foreign, and Internet resources contain a considerable amount of information covering different types of questions on the history of the Bologna process, its normative and regulatory completion and technical implementation, there is practically no scientific literature available which would contain a large-scale analysis of the international political aspects of the Bologna process in Russia. Its politics forming function is hard to be found to be described explicitly and in full. In this regard, the significant contribution made in recent years by the researchers of MGIMO (U) in the study of this problem should be noted.

Modern globalization has led to an increase in new instruments of influence, among which higher education is to be mentioned. The focus is on the notion of "higher education", quantitative indicators and qualitative characteristics of the processes of its internationalization, and the thesis of the "politics-forming" function of higher education.

The international political influence of higher education at the global and national levels have been gradually increasing. Modern universities weaken state sovereignty and put the question of the need to transform the "regulator state" into a "catalyst for progress" state on the agenda. In addition, varying degrees of access to higher education leads to increased social tensions on the global and national levels, where the availability of a prestigious system of higher education is becoming a significant factor for different countries and states. The role of higher education is increasing at the country level, where it is considered to be an integral part of civil society and a factor in the democratization of public life [2].

The future of the European Area of Higher Education depends on the ability of its members to overcome five major problems, including: a number of states joining the process only for the sake of membership in the European community; clustering of space into "center" and "periphery"; socio-political barriers to academic mobility; low level of social involvement in the development of the process; weak positioning of the "Bologna brand" in the international arena.

The Bologna process, at the present stage, is considered to be a complicated phenomenon, characterized by a lack of clear action plans and implementation strategies; there is no unambiguous scenario for its further development

The decision of Russia to join the European Higher Education Area was initially of a political nature because of the priority of the European vector in development of Russia in general in the early 2000s and the country's ambition to become a full member of a large-scale European initiative played it's important role in decision making. Due to the rapid accession, Russia's participation in the Bologna process was perceived ambiguously by the Russian academic community. Both political and social benefits were expected from the Russian participation in the process, but very serious risks were predicted. First of all, there is risk of reducing the quality of Russian education and brain drain.

These days, the Russian higher school is more oriented towards the American model of an innovative university, while its geographical priorities shift from the European model to the Eurasian vector. Nevertheless, a number of initiatives launched by the Ministry of Education in 2014 indicate that Russia's participation in the European Higher Education Area has the potential for further development.

Russia's participation in the Bologna process is positively influencing the overall image of the country, and is increasing its level of integration into the world educational system. Mechanisms for increasing the autonomy of universities and developing student-centered and studentoriented studying, as well as studying the successful experience of Russian partners in the Bologna process, can help to advance in this direction. At the moment, the effectiveness of Russian participation in the European Higher Education Area is limited due to its statecenteredness, the lack of systematic planning for the medium and long term outlook.

Despite a number of difficulties that arise in Russia connected with the Bologna process (the risk of reorienting the educational space of the CIS countries from traditional cooperation with Russian universities to partnership with Western ones, as well as the risk of "brain drain" to the West), the mechanisms of the European Higher Education Area can potentially enhance Russia's dialogue with the CIS countries and the EU. Russia's participation in the European Higher Education Area, where the majority of the CIS member states have eventually entered, prevented the fragmentation of the CIS educational space into pro-Russian 
and pro-European ones. Moreover, the mechanisms of the European Higher Education Area can be effectively used to preserve the Russian language space and attract Russianspeaking students to Russian universities within the framework of, for example, double diploma programs.

The European Higher Education Area is also the key to strengthening the relations between Russia and Europe through the intensification of its least politicized, cultural and educational component. Being a multi-vector and multilevel process, the European Higher Education Area acts as a platform for cooperation not only at the governmental level, but also at the level of universities, student and academic communities.

Thus, we can draw the following conclusions.

The main trend that influences the transformation of the political and social role of higher education in the world is the scientific globalization, the main features of which are internationalization, a sharp global increase in the number of students, the commercialization of higher education, and the emergence of a significant number of transnational providers of educational services.

The global "scientific revolution" has an increasing impact at three levels - global, country and in-country levels accordingly. It transforms the state-centered model of the world, acts as one of the indicators of state power in the modern world ("academic" superpower states), and also becomes a factor of social tension at the country and global levels, while contributing, at the same time, to democratization of public life and performing many related social functions at the country level.

The Bologna process is considered to be an example of the internationalization of higher education at the regional and European level. It is also an attempt to collectively maximize the impact of the opportunities created by the global "academic revolution". It is quite significant that, on the European continent, the vector was taken to create its own common European (and not American or jointly with the US) version of the harmonization of higher education systems [3]. The further development of the Bologna process requires overcoming of five major international and political challenges, which include: joining to the process by a number of states only for the sake of membership in the European "club"; clustering of the scientific and educational space into "center" and "periphery"; socio-political barriers to academic mobility; low level of social involvement in the development of the process; weak positioning of the "Bologna brand" on the international arena.

The decision of Russia joining the Bologna process was of a political nature, establishing the country's desire to become a full member of a large-scale European initiative. Overcoming internal disagreements and eventually Russia's admission to the Bologna process where several member countries of the European Higher Education Area were initially against Russia's participation in the process. This also symbolized the predominance of the trend towards rapprochement between Russia and Western European countries in the early 2000s. At the same time, Russia's accession to the Bologna process aroused a cautious reaction from the Russian academic community, as an example of the difficulties that Russia has to be facing, unlike countries which clearly aim at European integration.

Russia, as before the revolution and as in the Soviet era used various educational tools to strengthen its political positions in the world. The need for the development of these channels of "soft power" is now recognized much more clearly. Russia's participation in the Bologna process positively influences the overall image of the country, increasing its level of integration into the world educational system [4].

\section{CONCLUSION}

The mechanisms of the European Higher Education Area can potentially help to strengthen Russia's relations with the CIS countries and the EU. At the same time, the effectiveness of Russian policy in this direction is unfortunately limited by the lack of systematic planning for the long term.

\section{REFERENCES}

[1] The Bologna Declaration of 19 June 1999. URL http://www.bologna-bergen2005.no/Docs/00 Main_doc/990719B0LOGNA_DECLARATION.PDF/

[2] Nye J. The Future of Power. New York: Public Affairs: 2011.

[3] Making the most of our potential : Consolidating the European Higher Education Area// Bucharest Communiqué of 27 April 2012. URL

http://www.ehea.info/Uploads/\%281\%29/Bucharest\%20Communique $\% 202012 \% 281 \% 29$.pdf.

[4] Tomusk V. The Bologna Process and the Enlightenment Project: A Bird's Eye View from the Bottom of the Slope// European Education: Issues and Studies. 2008. №2 (3). 